Maria Karcz-Kaczmarek ${ }^{*}$

\title{
NARODOWY INSTYTUT WOLNOŚCI - CENTRUM ROZWOJU SPOŁECZEŃSTWA OBYWATELSKIEGO: DYLEMATY, WYZWANIA I PERSPEKTYWY
}

Społeczeństwo obywatelskie to wywodząca się ze starożytności koncepcja będąca centralnym pojęciem filozofii politycznej Arystotelesa (koinonia politike). Pojęcie to rozumiane było jako etyczno-polityczna wspólnota wolnych obywateli pod rządami prawa, w ramach której realizował się cel (telos) człowieka pojmowanego jako istota polityczna (politikon zoon). Według Arystotelesa miasto-państwo (polis) nie powinno sprowadzać dóbr jednostkowych do sumy, ale realizować wspólne dobro społeczności. Wspólnota obywatelska i polityka miały kreować wspólną przestrzeń, w której obywatele kształtują swoją osobowość poprzez działania na forum publicznym. Tak rozumiana wspólnota polityczna stanowić miała źródło etycznej doskonałości. Do arystotelesowskiej „wspólnoty politycznej” nawiązywał Cyceron, opisując ład społeczny republiki rzymskiej (civilis societas). W Starożytnym Rzymie społeczeństwo obywatelskie stanowiło sferę współistnienia rozumu i sprawiedliwości oraz obywatelskiej partycypacji w życiu wspólnoty politycznej. Społeczeństwo obywatelskie rozumiano jako jedność (wspólnotę) zbudowaną na uniwersalistycznym rozumieniu obywatelstwa, przy jednoczesnym przekonaniu o sile in-

" Maria Karcz-Kaczmarek - doktor nauk prawnych, Katedra Prawa Administracyjnego i Nauki Administracji, Uniwersytet Łódzki. 
teresów prywatnych. Państwo rozumiane było przez Cycerona jako wspólna własność członków samorządnej wspólnoty obywatelskiej (res populi). Dobro i prawa państwa stanowić miały najwyższą wartość. Państwo - rzecz wspólna i współdziałająca dla dobra ogólnego - było dopełnieniem człowieka. W klasycznym podejściu idea społeczeństwa obywatelskiego zbudowana była zatem na wartościach wspólnotowych, takich jak dobro wspólne ${ }^{1}$.

Wraz z upływem czasu rozumienie wskazanej koncepcji naukowej ulegało zmianie. W średniowieczu św. Augustyn odróżniał społeczeństwo obywatelskie, rozumiane jako wspólnota ziemska, od wspólnoty niebieskiej. Na ugruntowanie się terminu „społeczeństwo obywatelskie" istotny wpływ miały myśli polityczne oświecenia. Filozof John Locke utożsamiał civil society (efekt zawarcia umowy społecznej) z political society, w którym zakres działania władzy państwowej ograniczony jest do tego, co wynika z celu umowy społecznej. Celem umowy społecznej miało być zapewnienie bezpieczeństwa prawnego. W konstrukcji Locke’a społeczeństwo obywatelskie to społeczeństwo zorganizowane zarówno w państwo, jak i inne swobodnie kształtujące się formy instytucjonalne. Z kolei według Georga Wilhelma Friedricha Hegla społeczeństwo obywatelskie (bilrgerliche Gesellschaf) to społeczność pośrednia między rodziną a państwem, pomiędzy tym, co prywatne, a tym, co publiczne. Społeczeństwo obywatelskie, według Hegla, funkcjonuje poza zakresem bezpośredniego zainteresowania państwa, ale ma dla niego istotne znaczenie. Tak pojmowane społeczeństwo obywatelskie funkcjonuje w sferze stosunków ekonomiczno-społecznych, gdzie państwo pozwala obywatelom na przejawianie oddolnej i swobodnej inicjatywy.

We współczesnych naukach społeczno-politycznych wyodrębnia się dwie grupy (tradycje) rozumienia terminu „społeczeństwo obywatelskie”. Jedna z tradycji odwołuje się do „wspólnotowych” idei Arystotelesa i Cycerona oraz poglądów Locke’a. Zgodnie z tym rozumie-

${ }^{1}$ W. Osiatyński, Rzeczpospolita obywateli, Warszawa 2004, s. 95 i n. Por. Słownik socjologii i nauk społecznych, red. G. Marshall, Warszawa 2004, s. 347; F. Kalinowska, Kompendium wiedzy o społeczeństwie, cz. 2, Warszawa 2007, s. 402-403. 
niem społeczeństwo obywatelskie to ogół funkcjonujących w ramach obowiązującego prawa instytucji politycznych („rządowych”) oraz instytucji społecznych („pozarządowych”), umożliwiających obywatelom korzystanie $\mathrm{z}$ ich praw politycznych i ekonomicznych w ramach gospodarki rynkowej. Druga tradycja, przedstawicielem której obecnie jest filozof Cornelius Castoriadis, nawiązuje do poglądów Hegla. W tym ujęciu społeczeństwo obywatelskie to znajdująca się poza domeną działania władz publicznych „pozarządowa” sfera życia zbiorowego, regulowana lub kontrolowana w określonym przez prawo stopniu przez władze publiczne. Tak rozumiane społeczeństwo obywatelskie tworzą zróżnicowane organizacje społeczne, takie jak związki zawodowe, grupy interesów, firmy, a nawet grupy rekreacyjne. Dobrowolne i niezależne od władzy instytucje, stanowiąc część zbiorowego życia społeczeństwa, wpisują się w praktyczne funkcjonowanie demokratycznych struktur państwa².

Uogólniając, społeczeństwo obywatelskie rozumiane może być jako ogół względnie niezależnych wobec państwa instytucji, organizacji i stowarzyszeń działających w sferze publicznej. Społeczeństwo to stanowi autonomiczny byt zdolny równoważyć władzę państwową, charakteryzujący się aktywnością, zdolnością do samoorganizacji oraz wpływem na decyzje publiczne. Idea i rozwój społeczeństwa obywatelskiego pozostają w ścisłym związku z praktyczną realizacją wyrażonej expressis verbis w preambule Konstytucji RP zasady pomocniczości (subsydiarności). Biorąc pod uwagę ustalenia doktryny oraz obowiązujące przepisy, stwierdzić należy, że rolą państwa powinno być tworzenie warunków (w tym finansowych i instytucjonalnych) dla rozwoju działań obywatelskich oraz zachęcenie do podejmowania zróżnicowanych oddolnych aktywności, m.in. przez wskazywanie na płynące z tego rodzaju aktywności korzyści dla obywateli i ich wspólnot. Tego rodzaju działania władzy publicznej będą sprzyjały rozwojowi społeczeństwa obywatelskiego, a tym samym wpisywać będą się w realizację zasady pomocniczości. Jednocześnie jednak działania państwa nie mogą doprowadzić do centralnego sterowania społeczeństwem obywatelskim, poprzez narzucanie obywatelom określonej działalności

\footnotetext{
${ }^{2}$ F. Kalinowska, Kompendium..., cz. 2, s. 402-403.
} 
lub tworzenie różnego rodzaju barier w podejmowaniu działań niemieszczących się w sferze zainteresowania władz publicznych. Funkcjonowanie tego rodzaju rozwiązań prawnych stanowiłoby bowiem całkowite przekreślenie idei społeczeństwa obywatelskiego, które musi rozwijać się swobodnie i samodzielnie. Stwierdzenie to nie oznacza jednak, że państwo nie może wspierać, koordynować lub wyznaczać ram prawnych i instytucjonalnych rozwoju podmiotów wchodzących w skład społeczeństwa obywatelskiego.

Wydaje się, że obecnie zarówno w doktrynie nauk społeczno-politycznych, jak i na gruncie przepisów prawnych dominuje heglowskie podejście zawężające rozumienie społeczeństwa obywatelskiego do „trzeciego sektora” organizacji społeczeństwa, czyli różnego rodzaju organizacji pozarządowych, w szczególności stowarzyszeń i fundacji. Należy podkreślić, że pojęcie społeczeństwa obywatelskiego występuje zarówno w przepisach i dokumentach urzędowych UE, jak i w ustawodawstwie krajowym. W dokumentach Komisji Wspólnot Europejskich społeczeństwo obywatelskie definiowane jest jako zrzeszenie grupujące w szczególności organizacje związkowe i organizacje pracodawców, organizacje pozarządowe, stowarzyszenia zawodowe, organizacje dobroczynne, organizacje najbliższe ludziom (grass-root organisations), organizacje włączające obywateli w życie lokalne i gminne (organisations that involve citizens in local and municipal life), przy szczególnym wkładzie kościołów i wspólnot religijnych ${ }^{3}$. Z kolei przepis art. 11 ust. 2 TUE nakłada na instytucje unijne obowiązek utrzymywania otwartego, przejrzystego i regularnego dialogu ze stowarzyszeniami przedstawicielskimi i społeczeństwem obywatelskim. Traktat o funkcjonowaniu UE przewiduje zaś formalne usytuowanie przedstawicieli społeczeństwa obywatelskiego w strukturach instytucjonalnych UE. W myśl art. 300 ust. 2 TFUE przedstawiciele podmiotów reprezentujących społeczeństwo obywatelskie, w szczególności z dziedziny społeczno-ekonomicznej, obywatelskiej, zawodowej i kultury wchodzą w skład - pełniącego funkcje doradcze względem Parlamentu Europejskiego, Rady i Komisji - Komitetu Ekonomiczno-Społecznego. Do koncepcji społeczeństwa obywatelskiego odwołano

\footnotetext{
${ }^{3}$ White Paper: European Governance z 25.07.2001 r., COM(2001) 428.
} 
się także w umowie z 6.10.2010 r. o wolnym handlu między Unią Europejską i jej państwami członkowskimi z jednej strony, a Republiką Korei z drugiej strony ${ }^{4}$. We wstępie tej umowy umawiające się strony wskazały, iż są zdecydowane promować przejrzystość w zakresie wszystkich zainteresowanych stron, włącznie z organizacjami sektora prywatnego i społeczeństwa obywatelskiego. Wskazane porozumienie przewiduje sformalizowany „mechanizm dialogu ze społeczeństwem obywatelskim”, którym jest ustanowione, w celu „prowadzenia dialogu obejmującego związane ze zrównoważonym rozwojem aspekty handlu między stronami" ", Forum Społeczeństwa Obywatelskiego.

Na gruncie ustawodawstwa krajowego pojęcie społeczeństwa obywatelskiego występuje m.in. w rozporządzeniu Ministra Spraw Wewnętrznych i Administracji z 18.01.2007 r. w sprawie Biuletynu Informacji Publicznej ${ }^{6}$. Zgodnie z przepisem $\$ 11$ ust. 1 lit. b wskazanego aktu strona podmiotowa Biuletynu Informacji Publicznej zawiera w szczególności „inne informacje publiczne” opublikowanie, których wspiera rozwój społeczeństwa obywatelskiego. Należy zauważyć, iż rozwój społeczeństwa obywatelskiego stanowi obecnie zadanie publiczne, realizowane w zorganizowanych, instytucjonalnych formach. Wyrazem tego było ustanowienie w 2016 r. Pełnomocnika Rządu do spraw społeczeństwa obywatelskiego ${ }^{7}$. Zadaniem Pełnomocnika jest przygotowanie narodowego programu rozwoju społeczeństwa obywatelskiego, monitorowanie wdrażania programu, koordynowanie i monitorowanie współpracy organów administracji rządowej z sektorem organizacji pozarządowych i innych instytucji obywatelskich. W celu właściwej realizacji powierzonych zadań Pełnomocnik współdziała z właściwymi organami administracji rządowej oraz może podejmować współpracę z organami jednostek samorządu terytorialnego i organizacjami pozarządowymi ${ }^{8}$.

${ }^{4}$ Dz.U. z 2016 r. poz. 240. - dalej jako: umowa o wolnym handlu.

${ }^{5}$ Por. art. 13.13 umowy o wolnym handlu.

${ }^{6}$ Dz.U. Nr 10, poz. 68.

${ }^{7}$ Rozporządzenie Rady Ministrów z 8.01.2016 r. w sprawie ustanowienia Pełnomocnika Rządu do spraw społeczeństwa obywatelskiego (Dz.U. poz. 37).

${ }^{8}$ Por. $\$ 2-3$ rozporządzenia w sprawie ustanowienia Pełnomocnika Rządu do spraw społeczeństwa obywatelskiego. 
Rangę zadania publicznego, jakim jest rozwój społeczeństwa obywatelskiego, podkreśla uchwalenie 15.09.2017 r. ustawy o Narodowym Instytucie Wolności - Centrum Rozwoju Społeczeństwa Obywatelskiego'. Wskazany akt prawny rozpoczyna rozbudowana preambuła definiująca pojęcie społeczeństwa obywatelskiego oraz wskazująca na aksjologiczne wartości ustawy i ratio legis jej uchwalenia. Społeczeństwo obywatelskie, w myśl wskazanej ustawy, jest wspólną przestrzenią, która służy praktykowaniu cnót obywatelskich, takich jak odpowiedzialność za naród i wspólnoty lokalne, solidarność oraz zaangażowanie w budowę oddolnych instytucji obywatelskich. We wstępie do ustawy stwierdzono, że bez umiejętności dostrzegania i pomnażania dobra wspólnego zabraknie obywatelskich więzi społecznych, które są fundamentem kapitału społecznego. W preambule zwrócono także uwagę, że ideały społeczeństwa obywatelskiego wyraża „aktywność obywateli, oddolnie i na zasadach dobrowolności angażujących się w zorganizowane działania na rzecz dobra wspólnego, niosących pomoc i wsparcie potrzebującym oraz kształtujących pracą u podstaw zręby kultury narodowej i lokalnej, nawiązuje do wielkiego dziedzictwa polskiej wolności". Misją państwa polskiego ma być wspieranie wolnościowych i chrześcijańskich ideałów obywateli i społeczności lokalnych, odnoszących się do tradycji polskiej inteligencji, tradycji niepodległościowych, narodowych, religijnych, socjalistycznych oraz do tradycji ruchu ludowego. W pielęgnowaniu i rozwoju wskazanych ideałów ustawodawca dostrzega kontynuację wielowiekowych tradycji Rzeczypospolitej Polskiej oraz bogatego dziedzictwa wspólnoty jej wolnych obywateli.

Warto zauważyć, że zgodnie z preambułą powołanej ustawy Rzeczpospolita Polska dąży do zrównoważonego rozwoju społeczeństwa obywatelskiego zarówno w wymiarze terytorialnym, jak i tematycznym, szczególną ochroną otaczając „organizacje małe, krzewiące etos społecznikowski i pielęgnujące dziedzictwo lokalne". W ocenie ustawodawcy u podstaw motywacji prospołecznych, jak i postaw propaństwowych leży wypełnienia ideałów wolności. Zadaniem państwa pol-

${ }^{9}$ Dz.U. z 2018 r. poz. 1813 - dalej jako: ustawa wrześniowa lub ustawa o Narodowym Instytucie Wolności. 
skiego ma być także kształtowanie dojrzałego patriotyzmu, poprzez aktywną działalność na rzecz zwiększania zaangażowania obywateli i ich organizacji w życiu publicznym, przyczynianie się do zwiększania liczby inicjatyw oddolnych i lokalnych oraz poprawy instytucjonalnej zdolności organizacji obywatelskich do realizacji ich misji. Należy podkreślić, że w świetle ustaleń doktrynalnych dotyczących społeczeństwa obywatelskiego stanowi ono efekt dobrowolnej i oddolnej aktywność obywateli. Stąd też działania państwa w tej sferze muszą być podejmowane z pełną rozwagą, tak by środki służące do zachęcania (lub wsparcia) obywateli do samoorganizowania się, nie zostały odczytane przez zainteresowane środowiska społeczne jako środki wymuszania określonego rodzaju aktywności. Tego rodzaju działania mogłyby bowiem stanowić przejaw nadmiernego upolitycznienia czy wręcz centralizacji sfery społeczeństwa obywatelskiego, co stałoby w sprzeczności ze standardami demokratycznego państwa prawnego. Na mocy przepisów ustawy wrześniowej w celu wspierania rozwoju społeczeństwa obywatelskiego, a także działalności pożytku publicznego i wolontariatu $^{10}$, powołany został Narodowy Instytut Wolności - Centrum Rozwoju Społeczeństwa Obywatelskiego ${ }^{11}$, z siedzibą w mieście stołecznym Warszawie. Narodowy Instytut Wolności jest nadzorowaną przez Przewodniczącego Komitetu do spraw Pożytku Publicznego agencją wykonawczą w rozumieniu ustawy o finansach publicznych ${ }^{12}$. Warto zwrócić uwagę, że oba podmioty publiczne, tj. Narodowy Instytut Wolności Centrum Rozwoju Społeczeństwa Obywatelskiego i Komitet do spraw Pożytku Publicznego utworzone zostały na mocy ustawy wrześniowej. Forma agencji wykonawczej nie jest zarezerwowana dla określonego rodzaju zadań publicznych, ma ona znaczenie jedynie z punktu widzenia sektora finansów publicznych. Przez agencję wykonawczą, zgodnie $\mathrm{z}$ art. 18 u.f.p., rozumie się państwową osobę prawną tworzoną na podstawie odrębnej ustawy, w celu realizacji zadań państwa. Oznacza to, iż w obecnym stanie prawnym wspieranie rozwoju społeczeństwa obywatelskiego oraz działalności pożytku publicznego i wolontariatu stanowi

${ }^{10}$ W zakresie określonym w ustawie z 24.04.2003 r. o działalności pożytku publicznego i o wolontariacie (Dz.U. z 2018 r. poz. 450 ze zm.) - dalej jako: u.dz.p.p.w.

11 Zwany dalej Narodowym Instytutem Wolności lub Narodowym Instytutem.

${ }^{12}$ Ustawa z 27.08.2009 r. o finansach publicznych (Dz.U. 2017 r. poz. 2077 ze zm.) - dalej jako: u.f.p. 
zadanie publiczne, realizowane przez państwowy podmiot prawny działający na zasadach określonych ustawowo. Zgodnie z art. 23 ust. 2 ustawy o Narodowym Instytucie Wolności programy wspierania rozwoju społeczeństwa obywatelskiego przyjmuje w drodze uchwały Rada Ministrów. Zasady działania Narodowego Instytutu Wolności określają tzw. ustawa wrześniowa oraz jego statut. Statut nadawany jest w drodze rozporządzenia przez Przewodniczącego Komitetu do spraw Pożytku Publicznego. Ustalając treść statutu, Przewodniczący wskazanego Komitetu powinien mieć na uwadze sprawne i efektywne zarządzanie środkami finansowymi i wykonywanie zadań. Nadawany przez organ nadzoru statut określa szczegółowy zakres zadań i tryb pracy organów Narodowego Instytutu, jego organizację oraz wartość majątku nieprzekraczającego kwoty 200000 zł, powyżej którego rozporządzanie nim przez Dyrektora Narodowego Instytutu wymaga zgody Rady Narodowego Instytutu. Warto zwrócić uwagę na postanowienia ustawy o finansach publicznych, przewidujące, że w celu ujednolicenia i zapewnienia przejrzystej organizacji wewnętrznej agencji wykonawczych Rada Ministrów może skorzystać, w drodze rozporządzenia, z fakultatywnego upoważnienia do określenia wymogów, jakie powinien spełniać statut agencji wykonawczej. W przypadku uchwalenia wskazanego rozporządzenia będzie ono miało zastosowanie także do Narodowego Instytutu. Zasady gospodarki finansowej Narodowego Instytutu określa w pierwszej kolejności ustawa o finansach publicznych oraz ustawa tworząca Instytut. Oznacza to, iż projekt rocznego planu finansowego wskazanej agencji wykonawczej ustala Dyrektor Instytutu w porozumieniu z podmiotem sprawującym nadzór nad agencją, czyli Przewodniczącym Komitetu do spraw Pożytku Publicznego. Po zatwierdzeniu przez podmiot sprawujący nadzór projekt przekazywany jest do $\mathrm{Mi}$ nistra Finansów, w trybie i terminach określonych w przepisach dotyczących prac nad projektem ustawy budżetowej ${ }^{13}$. Dyrektora Instytutu ${ }^{14}$ oraz trzech członków zwyczajnych Rady Narodowego Instytutu powołuje Przewodniczący Komitetu do spraw Pożytku Publicznego, do kompetencji którego należy także powołanie Przewodniczącego Rady Narodowego Instytutu Wolności.

\footnotetext{
${ }^{13}$ Por. art. 21 u.f.p.

${ }^{14}$ Kadencja Dyrektora Narodowego Instytutu Wolności wynosi 5 lat.
} 
Zgodnie z ustawą o działalności pożytku publicznego i o wolontariacie Komitet do spraw Pożytku Publicznego jest organem administracji rządowej właściwym w sprawach pożytku publicznego i wolontariatu, w tym programowania, koordynowania i organizowania współpracy organów administracji publicznej i podmiotów działających w sferze pożytku publicznego. Zgodnie z art. 34c u.dz.p.p.w. pracami wskazanego Komitetu kieruje Przewodniczący, który wchodzi w skład Rady Ministrów ${ }^{15}$. W świetle postanowień art. 147 ust. $4^{16}$ oraz art. 149 ust. $3^{17}$ Konstytucji RP stwierdzić należy, że do Przewodniczącego Komitetu do spraw Pożytku Publicznego będą miały zastosowanie przepisy odnoszące się do ministra kierującego działem administracji rządowej. Z kolei powoływany przez Przewodniczącego Komitetu do spraw Pożytku Publicznego Dyrektor Narodowego Instytutu wchodzi w skład tego Komitetu. Zauważyć zatem należy, że Dyrektora Narodowego Instytutu łączy powiązanie personalno-organizacyjne z Przewodniczącym Komitetu do spraw Pożytku Publicznego. Zależność ta uwidacznia się w sposobie powoływania Dyrektora Instytutu oraz w jego relacjach z Przewodniczącym Komitetu do spraw Pożytku Publicznego na forum tegoż Komitetu. Analiza przepisów ustawy wrześniowej, ustawy o finansach publicznych oraz ustawy o działalności pożytku publicznego i o wolontariacie wskazuje zatem na umiejscowienie Instytutu w strukturze centralnej administracji rządowej oraz na powiązania personalno-organizacyjne pomiędzy organami Instytutu (czyli Dyrektorem i Radą), a Przewodniczącym Komitetu do spraw Pożytku Publicznego.

Ustawa wrześniowa zawiera rozbudowany katalog szczegółowych zadań realizowanych przez Narodowy Instytut Wolności. Biorąc pod uwage przepis art. 23 ust. 1 tej ustawy, stanowiący, że „Naro-

15 Art. 34a ust. 2 u.dz.p.p.w. Pierwszym Przewodniczącym Komitetu do spraw Pożytku Publicznego został Minister Kultury i Dziedzictwa Narodowego. Por. https:// wiadomosci.wp.pl/piotr-glinski-zostal-przewodniczacym-komitetu-ds-pozytku-publicznego-6187740983842433a (dostęp: 9.11.2018 r.).

16 Przepis stanowi, że w skład Rady Ministrów mogą być powoływani przewodniczący określonych w ustawach komitetów.

17 Do przewodniczącego komitetu, o którym mowa w art. 147 ust. 4 Konstytucji RP, stosuje się odpowiednio przepisy odnoszące się do ministra kierującego działem administracji rządowej. 
dowy Instytut zarządza programami wspierania rozwoju społeczeństwa obywatelskiego, realizując zadania, o których mowa w art. 24", stwierdzić należy, że podstawowym celem działania Instytutu jest dysponowanie programami dotyczącymi rozwoju społeczeństwa obywatelskiego. Programy te uchwalane są przez Radę Ministrów po przeprowadzeniu konsultacji z organizacjami pozarządowymi oraz podmiotami wymienionymi w art. 3 ust. 3 u.dz.p.p.w. Zarządzanie programami wspierania rozwoju społeczeństwa obywatelskiego przez utworzoną w tym celu agencję wykonawczą przyczynić ma się do wyrównywania szans w sektorze działalności publicznej. Działania Instytutu niwelować mają dotychczasowe problemy związane z dużym rozwarstwieniem organizacji oraz nierównym dostępem do środków publicznych, w szczególności przez organizacje mało znane lub rozpoczynające dopiero swoją działalność. Zarządzanie przez Narodowy Instytut grantami instytucjonalnymi dedykowanymi dla małych organizacji, jak i dobór priorytetów konkursów uwzględniający działania, na które w ostatnich latach trudno było zdobyć dofinansowanie, ma wyrównywać szanse w sektorze organizacji pozarządowych. Poza tym wspierane mają być także mniej formalne grupy społeczeństwa obywatelskiego, poprzez regranting i wsparcie szkoleniowe ${ }^{18}$. Zgodnie $\mathrm{z}$ informacją umieszczoną na oficjalnej stronie Prezydenta RP Instytut wdrażać ma politykę państwa w zakresie rozwoju społeczeństwa obywatelskiego, opartą na zasadach otwartości, konkurencyjności i przejrzystości. Jego rolą ma być wspieranie rozwoju społeczeństwa obywatelskiego w Polsce poprzez wzmacnianie zorganizowanej i dobrowolnej aktywności obywateli na rzecz różnorakich ważnych społecznie celów. Działalność ta nawiązywać ma do „wielowiekowego dziedzictwa polskiej wspólnoty wolnych obywateli i jednocześnie wypełniać ideały wolności” ${ }^{\prime 1}$.

${ }^{18}$ Uzasadnienie rządowego projektu ustawy o Narodowym Instytucie Wolności - Centrum Rozwoju Społeczeństwa Obywatelskiego, VIII kadencja, druk sejm. nr 1713. Por. też http://legislacja.rcl.gov.pl/docs//2/12293252/12399851/12399852/ dokument295101.pdf (dostęp 9.11.2018 r.).

19 Por. Informacja w sprawie ustawy z dnia 15 września 2017 r. o Narodowym Instytucie Wolności - Centrum Rozwoju Społeczeństwa Obywatelskiego, http://www.prezydent. pl/prawo/ustawy/podpisane/art,27,pazdziernik-2017-r-.html (dostęp: 9.11.2018 r.). 
Zadania Narodowego Instytutu wymienione zostały w przepisie art. 24 ust. 3 ustawy wrześniowej. Wskazany katalog obejmuje takie działania, jak: wspieranie zaangażowania obywateli, organizacji pozarządowych oraz innych zorganizowanych form społeczeństwa obywatelskiego w życie publiczne, procesy kształtowania polityk publicznych i podejmowania decyzji; wspieranie obywatelskiej kontroli nad funkcjonowaniem instytucji publicznych i instytucji zaufania publicznego oraz zwiększenie ich przejrzystości i przestrzegania reguł dobrego rządzenia. Do Instytutu należy także: wspieranie oddolnej aktywności obywatelskiej, wzmacnianie etosu społecznikowskiego obywateli, wspieranie i upowszechnianie wolontariatu; podtrzymywanie i upowszechnianie kultury oraz zakorzenionej w chrześcijańskim dziedzictwie tradycji narodowej i lokalnej, pielęgnowanie polskości oraz rozwoju świadomości narodowej, obywatelskiej i kulturowej, jak i solidarności i wrażliwości społecznej; promocja poszanowania i ochrony praw człowieka i obywatela. Zadaniem nowo utworzonego podmiotu publicznego jest ponadto edukacja obywatelska i kształtowanie postaw obywatelskich oraz wspieranie zaangażowania obywateli i organizacji obywatelskich w realizację zadań z zakresu edukacji formalnej i nieformalnej, prowadzenie i wspieranie programów badań dotyczących społeczeństwa obywatelskiego. Instytut uczestniczy także w realizacji międzynarodowych programów wspierania rozwoju społeczeństwa obywatelskiego, w tym programów współfinansowanych ze środków zagranicznych oraz w upowszechnianiu informacji w środowisku organizacji pozarządowych oraz innych zorganizowanych formach społeczeństwa obywatelskiego, o planowanych i ogłaszanych konkursach. Do zadań Instytutu należy również podejmowanie działań popularyzatorskich dotyczących efektów zrealizowanych zadań oraz prowadzenie repozytorium modelowych przedsięwzięć, dobrych praktyk, rezultatów i produktów wypracowanych w ramach programów wspierania rozwoju społeczeństwa obywatelskiego. Co ciekawe, Narodowy Instytut podejmuje także działania dotyczące wspierania ochrony środowiska oraz praw zwierząt. W myśl przepisu art. 24 ust. 3 pkt 12 ustawy wrześniowej Instytut zobligowany jest do realizacji innych zadań zlecanych przez Przewodniczącego Komitetu, przy jednoczesnym zapewnieniu przez ten podmiot środków finansowych na ich realizację. Wskazane postanowienie podkreśla nie 
tylko silną pozycję ustrojową oraz uprawnienia merytoryczne Przewodniczącego Komitetu względem Narodowego Instytutu, ale także zabezpiecza finansowe podstawy jego działalności poprzez ustawowy zakaz zlecania zadań publicznych bez jednoczesnego przekazywania niezbędnych do ich realizacji środków finansowych.

Wskazane w ustawie zadania Narodowy Instytut realizuje samodzielnie lub zleca ich realizację wyłonionym w drodze otwartego konkursu ofert organizacjom pozarządowym oraz podmiotom wymienionym w art. 3 ust. 3 ustawy o działalności pożytku publicznego i o wolontariacie. Narodowy Instytut może uczestniczyć w realizacji programów operacyjnych, o których mowa w ustawie z 11.07.2014 r. o zasadach realizacji programów w zakresie polityki spójności finansowanych w perspektywie finansowej 2014-202020, a także przystępować do programów lub projektów współfinansowanych ze środków pochodzących z budżetu Unii Europejskiej oraz niepodlegających zwrotowi środków z pomocy udzielanej przez państwa członkowskie Europejskiego Porozumienia o Wolnym Handlu (EFTA) ${ }^{21}$.

Analiza obowiązujących przepisów wskazuje, że katalog zadań realizowanych przez Narodowy Instytut w pewnej mierze jest zbliżony lub wręcz zbieżny ze wskazanymi w przepisie art. 34b ust. 1 u.dz.p.p.w. zadaniami Komitetu do spraw Pożytku Publicznego. Zgodnie z przepisami ustawy o działalności pożytku publicznego i o wolontariacie Komitet podejmuje bowiem działalność także w sferze społeczeństwa obywatelskiego. W myśl przepisu art. 34b u.dz.p.p.w. do Komitetu należy koordynowanie i monitorowanie współpracy organów administracji rządowej ze zorganizowanymi formami społeczeństwa obywatelskiego, przygotowywanie i konsultowanie programów wspierania rozwoju społeczeństwa obywatelskiego oraz monitorowanie ich wdrażania, a także opracowywanie i opiniowanie projektów aktów prawnych w zakresie rozwoju społeczeństwa obywatelskiego. Ponadto Komitet współpracuje w sprawach związanych z rozwojem społeczeństwa obywatelskiego z innymi państwami, organizacjami oraz instytucjami

${ }^{20}$ Dz.U. z 2018 r. poz. 1431 ze zm.

${ }^{21}$ Są to środki publiczne, o których mowa w art. 5 ust. 1 pkt 2 u.f.p. 
międzynarodowymi i zagranicznymi. Do zadań wskazanego organu administracji rządowej należy również współpraca w przygotowywaniu sprawozdań i raportów z realizacji wiążących Rzeczpospolitą Polską umów międzynarodowych dotyczących rozwoju społeczeństwa obywatelskiego oraz przedstawianie opinii w sprawie możliwości przystąpienia przez Rzeczpospolitą Polską do umów międzynarodowych dotyczących rozwoju społeczeństwa obywatelskiego. Podejmowanie zbliżonej działalności przez dwa odrębne organy administracji rządowej ${ }^{22}$ może budzić pewne wątpliwości zarówno natury organizacyjnej, jak i merytorycznej. Wskazany stan prawny może bowiem prowadzić do sporów kompetencyjnych. Funkcjonujące zaś pomiędzy Komitetem a organami Narodowego Instytutu Wolności powiązania personalno-organizacyjne mogą rzutować na samodzielność i niezależność działania Narodowego Instytutu. Realizowanie zadań dotyczących rozwoju społeczeństwa obywatelskiego przez Komitet do spraw Pożytku Publicznego budzi pewne wątpliwości także z uwagi na treść art. 1 u.dz.p.p.w. W myśl tego przepisu Komitet jest organem administracji rządowej właściwym w sprawach pożytku publicznego i wolontariatu, w tym programowania, koordynowania i organizowania współpracy organów administracji publicznej i podmiotów działających w sferze pożytku publicznego. Przepis ten, określając zakres właściwości rzeczowej Komitetu w sferze pożytku publicznego, nie wskazuje na jego kompetencje w sprawach szeroko pojętego społeczeństwa obywatelskiego.

Odnosząc się do zakresu zadań utworzonego w 2017 r. Narodowego Instytutu Wolności, należy stwierdzić, że realizuje on w większości zadania będące dotychczas w kompetencji ministra właściwego do spraw zabezpieczenia społecznego, w odniesieniu do tzw. trzeciego sektora (organizacji pozarządowych oraz wolontariatu) ${ }^{23}$. W uzasadnieniu ustawy wrześniowej wskazano, że w sensie operacyjnym,

${ }^{22}$ Zgodnie z art. 1a u.dz.p.p.w. Komitet do spraw Pożytku Publicznego jest organem administracji rządowej właściwym w sprawach pożytku publicznego i wolontariatu. Z kolei art. 29 ustawy o Narodowym Instytucje Wolności stanowi, że w przypadku realizacji zadań Narodowego Instytutu organem administracji publicznej w rozumieniu ustawy o działalności pożytku publicznego i o wolontariacie jest Dyrektor.

${ }^{23}$ Por. przepis art. 31 ust. 1 ustawy z 4.09 .1997 r. o działach administracji rządowej w brzmieniu sprzed nowelizacji z 15.09.2017 r. (Dz.U. z 2017 r. poz. 888). 
Narodowy Instytut przejmie z Departamentu Ekonomii Społecznej i Pożytku Publicznego Ministerstwa Rodziny, Pracy i Polityki Społecznej zarządzanie Funduszem Inicjatyw Obywatelskich (FIO) oraz Funduszem Wspierania Organizacji Pożytku Publicznego. W przyszłości wraz z dostępnością i pozyskiwaniem nowych środków, Narodowy Instytut będzie rozwijał kolejne programy wspierania rozwoju społeczeństwa obywatelskiego w Polsce, w tym Polski Korpus Solidarności (program wspierania wolontariatu długoterminowego i systematycznego), Fundusz Grantów Instytucjonalnych (programy wspierania rozwoju i zwiększania kompetencji organizacji) oraz Fundusz Inicjatyw Edukacyjnych (programy rozwoju uniwersytetów ludowych oraz edukacji obywatelskiej i patriotycznej). Podstawową funkcją analizowanej agencji wykonawczej jest jednakże dystrybucja środków publicznych w omawianym zakresie spraw społecznych. Odnotować zatem należy, że Narodowy Instytut wraz z Komitetem do spraw Pożytku Publicznego realizują obecnie ogół zadań w sferze pożytku publicznego i wolontariatu należących dotychczas do ministra właściwego do spraw zabezpieczenia społecznego. Wskazane now outworzone podmioty publiczne podejmują także zadania dotyczące rozwoju społeczeństwa obywatelskiego stanowiące novum, nie były one bowiem przewidziane wprost w dotychczasowym ustawodawstwie. Dodatkowo, na mocy ustawy wrześniowej, umożliwiono wojewodom ustanawianie pełnomocników do spraw społeczeństwa obywatelskiego, do zadań których należeć ma monitorowanie wdrażania programów wspierania rozwoju społeczeństwa obywatelskiego oraz rocznych lub wieloletnich program współpracy z organizacjami pozarządowymi, a także koordynowanie współpracy jednostek administracji rządowej w województwie z organizacjami pozarządowymi, które zgodnie z zakresem swoich zadań statutowych działają na rzecz rozwoju społeczeństwa obywatelskiego ${ }^{24}$.

Z praktycznego i teoretycznoprawnego punktu widzenia zagadnieniem o kluczowym znaczeniu są zasady i procedury dysponowania środkami publicznymi przeznaczonymi na wspieranie inicjatyw społecznych. Należy podkreślić, że ustawa wrześniowa w sensie procedu-

\footnotetext{
${ }^{24}$ Por. art. $41 \mathrm{k}$ i 411 u.dz.p.p.w.
} 
ralnym stanowi odejście od zasad przyjętych dotychczas w ustawie o działalności pożytku publicznego i o wolontariacie. Przepis art. 30 powołanej ustawy stanowi bowiem, że Narodowy Instytut realizuje programy samodzielnie lub w drodze otwartego konkursu ofert. Regulamin konkursu ustala Dyrektor Instytutu, a następnie zatwierdza go Rada. Ustawa nie precyzuje także zasad dysponowania środkami na rozwój instytucjonalny organizacji pozarządowych oraz podmiotów, o których mowa w art. 3 ust. 3 u.dz.p.p.w., w tym kosztów organizacyjnych i administracyjnych ich działalności. Przepis art. 31 ustawy wrześniowej stanowi jedynie, że „Narodowy Instytut może dofinansować rozwój instytucjonalny [...]”, nie wskazując wyraźnie, czy w tej sferze będą organizowane jakiekolwiek konkursy. Odnosząc się do treści wskazanych przepisów, należy stwierdzić, że ostateczna decyzja o wyborze właściwej w danym programie wspierania rozwoju społeczeństwa obywatelskiego procedury należeć będzie do Dyrektora Instytutu. Zgodnie bowiem z przepisem art. 8 ust. 1 ustawy Dyrektor kieruje działalnością Narodowego Instytutu, w szczególności podejmuje decyzje we wszystkich sprawach niezastrzeżonych dla Rady. Przewidziana ustawowo na rzecz Dyrektora władza dyskrecjonalna umożliwia mu prowadzenie elastycznej polityki proceduralnej we wskazanym zakresie, jednocześnie jednak brak ustawowego doprecyzowania zasad dysponowania środkami publicznymi może przyczyniać się do uznaniowego przydzielania środków finansowych. Praktycy trzeciego sektora za podstawowy mankament nowej ustawy uznali wprowadzenie możliwości swobodnego kształtowania zasad dofinansowania programów społecznych oraz brak formalnych zabezpieczeń równego traktowania wszystkich organizacji pozarządowych ${ }^{25}$. Jednocześnie zgodzić należy się z poglądem, że podział środków w drodze otwartego konkursu nie stanowi remedium na wszelkie nierówności, czy uznaniowe podejmowanie decyzji, ponieważ „założenia każdego konkursu, nawet najbardziej szczegółowo opisanego, mogą zostać wypaczone”26.

${ }^{25}$ I. Dutkiewicz, Narodowy Instytut Wolności. Czy jest się czego bać?, https://publicystyka.ngo.pl/narodowy-instytut-wolnosci-czy-jest-sie-czego-bac (dostęp: 10.01.2018 r.).

${ }^{26}$ Zob. wywiad z Wicepremierem i Ministrem Kultury i Dziedzictwa Narodowego P. Glińskim [w:] I. Dutkiewicz, W Polsce nie ma żadnego zagrożenia demokracji (wywiad $z$ P. Glińskim), https://publicystyka.ngo.pl/glinski-w-polsce-nie-ma-zadnegozagrozenia-demokracji (dostęp: 10.01.2018 r.). 
Wskazany ustawowy luz kompetencyjny i związane z nim uznanie administracyjne stanowi wyzwanie dla osób pełniących funkcje decyzyjne w Narodowym Instytucie w sferze ich rzetelności, bezstronności i obiektywizmu w wykonywaniu zadań publicznych. Należy zauważyć, iż działalność Dyrektora, który w przypadku realizacji zadań Narodowego Instytutu jest organem administracji publicznej w rozumieniu ustawy o działalności pożytku publicznego i o wolontariacie, podlega zaopiniowaniu przez Radę ${ }^{27}$. Przy czym przedstawiciele organizacji pozarządowych nie stanowią większości ${ }^{28}$ ustawowego składu Rady, z uwagi na co ich głos może zostać przegłosowany, a ponadto wyrażane przez Radę opinie nie mają charakteru wiążącego.

Uchwalenie i wejście w życie ustawy wrześniowej poprzedziły głosy jej oponentów wskazujące, że skutkować ona będzie centralizacją systemu wsparcia dla organizacji pozarządowych w Polsce ${ }^{29}$. Odnosząc się do głosów krytyki w uzasadnieniu ustawy podkreślono, że jej wejście w życie nie spowoduje centralizacji, ponieważ ustawa ma charakter jedynie kompetencyjny. Wprowadzone zmiany nie tworzą nowych uprawnień, a wyłącznie przenoszą część kompetencji ministra właściwego do spraw zabezpieczenia społecznego (obecnie Ministerstwa Rodziny, Pracy i Polityki Społecznej) na rzecz Komitetu do spraw Pożytku Publicznego, Przewodniczącego tego Komitetu oraz do Narodowego Instytutu. W uzasadnieniu stwierdzono, że wskazane podmioty „nie przejmują żadnych kompetencji innych ministrów w zakresie współpracy z organizacjami pozarządowymi w zakresie odpowiadającym obszarom ich działalności, ani innych organów administracji publicznej. Ustawa nie zmieni żadnych przepisów regulujących relacje między organizacjami i inicjatywami obywatelskimi a jednostkami samorządów terytorialnych [...]"30.

27 Por. art. 12 ustawy wrześniowej.

${ }^{28}$ W skład jedenastoosobowej Rady wchodzi pięciu przedstawicieli organizacji pozarządowych, por. art. 9 ust. 1 ustawy wrześniowej.

29 Por. m.in. H. Wujec, Władza zawłaszcza wszystko również NGO, https://publicystyka.ngo.pl/wladza-zawlaszcza-wszystko-rowniez-ngo (dostęp: 10.12.2017 r.).

${ }^{30}$ Por. Uzasadnienie... 
W świetle rozważań teoretycznych dotyczących koncepcji naukowej społeczeństwa obywatelskiego utworzenie organu centralnego zajmującego się rozwojem tego rodzaju społeczeństwa może budzić pewne wątpliwości. Społeczeństwo obywatelskie powinno kształtować i rozwijać się samoistnie i oddolnie jako ruch osób świadomie i aktywnie uczestniczących w życiu publicznym. Rozwój instytucji społeczeństwa obywatelskiego powinien być swobodny i dobrowolny, państwo nie może wymuszać jego tworzenia ani rozwoju w ściśle określonym kierunku. Jakiekolwiek formy władcze wykluczają bowiem istnienie społeczeństwa obywatelskiego, prowadzić mogą do funkcjonowania jego „zafałszowanej” wersji. Stwierdzenie to nie oznacza jednak, że państwo nie jest władne podejmować działań w sferze społeczeństwa obywatelskiego lub nie powinno promować i wskazywać na korzyści płynące z funkcjonowania i rozwoju tego społeczeństwa. Działania władz publicznych muszą jednak uwzględniać fakt, iż obecnie społeczeństwo nie jest homogeniczne. Wręcz przeciwnie, z uwagi na różnego rodzaju procesy społeczne, jak choćby migracje zarobkowe ${ }^{31}$ lub poakcesyjne ${ }^{32}$, społeczeństwo różnicuje się pod względem narodowościowym, wyznaniowym, światopoglądowym. Procesy te powinny być uwzględniane w działaniach faktycznych i koncepcyjnych władz publicznych. Utworzony w 2017 r. Narodowy Instytut Wolności - Centrum Rozwoju Społeczeństwa Obywatelskiego sprostać musi zatem wysokim oczekiwaniom, tak by jego działalność podejmowana była dla dobra wspólnego i służyła rozwojowi społeczeństwa obywatelskiego w jego obecnym, niejednorodnym kształcie. Działalność Instytutu nie może prowadzić do centralizacji systemu wydatkowania środków publicznych, a w konsekwencji - do zawężenia katalogu partycypantów programów wspierania rozwoju społeczeństwa obywatelskiego. Istotne znaczenie odgrywa zatem sprawowany przez Przewodniczącego Komitetu do spraw Pożytku Publicznego nadzór nad Narodowym Instytutem oraz działalność opiniodawcza Rady Insty-

${ }^{31}$ Szerzej zob. J. Łukaszewska-Bezulska, Migracje zarobkowe a kapitat społeczny na pograniczach kulturowych na przykładzie Opolszczyzny i Podlasia, „Studia Migracyjne - Przegląd Polonijny" 2015/2, s. 81-97.

${ }^{32}$ I. Grabowska, E. Jaźwińska, Migracje poakcesyjne Polaków i kapitał ludzki: transfer wiedzy, umiejętności, kompetencji, „Studia Migracyjne - Przegląd Polonijny” 2015/2, s. $53-81$. 
tutu. Dostrzegając ewentualne zagrożenia związane z uznaniowością w sferze wyboru procedury realizacji programów wspierania rozwoju społeczeństwa obywatelskiego, przewrotnie stwierdzić można, że należyte funkcjonowanie Narodowego Instytutu będzie najlepszym sprawdzianem jakości funkcjonowania społeczeństwa obywatelskiego w Polsce.

\section{Bibliografia:}

Grabowska I., Jaźwińska E., Migracje poakcesyjne Polaków i kapitał ludzki: transfer wiedzy, umiejętności, kompetencji, „Studia Migracyjne - Przegląd Polonijny" 2015/2

Kalinowska F., Kompendium wiedzy o społeczeństwie, cz. 2, Warszawa 2007

Łukaszewska-Bezulska J., Migracje zarobkowe a kapitał społeczny na pograniczach kulturowych na przykładzie Opolszczyzny i Podlasia, „Studia Migracyjne - Przegląd Polonijny" 2015/2

Osiatyński W., Rzeczpospolita obywateli, Warszawa 2004

Stownik socjologii i nauk społecznych, red. G. Marshall, Warszawa 2004 